\title{
Quasi Experimental Non Randomized Study on Effectiveness of Instructional Strategy on Knowledge, Practice and Quality of Life of Head and Neck Cancer Patients Receiving Radiotherapy in Selected Cancer Research Institute, Uttarakhand
}

\section{Kaveta Nigam ${ }^{1 *}$ and Kamli Prakash ${ }^{2}$}

${ }^{1}$ Department of Nursing, Vivekananda College of Nursing, Lucknow, UP, India

${ }^{2}$ Department of Nursing, Himalayan College of nursing, Lucknow, UP, India

\begin{abstract}
The cancer is a disease of cell in which the normal mechanism of the control of growth and proliferation has been altered. Annually, nearly 3 million people die of cancer in India. The Indian Council of Medical Research said in 2016 the total number of new cancer cases is expected to be around 1.45 million and the figure is likely to reach nearly 1.73 million new cases in 2020 . Over 0.736 million people are expected to succumb to the disease in 2016 while the figure is estimated to shoot up to 0.88 million by 2020. Data also revealed that only 12.5 percent of patients come for treatment in early stages of the disease.

Purpose: The Purpose was to educate the patients with Head and Neck Cancer undergoing radiation therapy about management of side effects to improve their quality of life.

Method: A Quantitative research approach with Quasi-experimental pre-test post-test design. The study was conducted in selected Cancer Research Institute, Dehradun, Uttarakhand. Consecutive sampling technique was used for data collection from 60 Head and neck cancer patients by using Structured Knowledge interview schedule, structured self-reported practice checklist and EORTCH \& N35 QLQ.

Result: The mean post-test knowledge score in experimental group was $18.70 \pm 3.06$ which was significantly higher than the control group $11.50 \pm 5.00$. The mean post-test practice score in experimental group was $16.40 \pm$ 1.86 which was significantly higher than the control group $10.00 \pm 3.01$. There was significant improvement in the Quality of Life of the patients in experimental group in different phases of radiation therapy. In multiple item scalesPain $\left(0.014\right.$ on $8^{\text {th }}$ day and $<0.001$ on $16^{\text {th }}$ day), swallowing $\left(<0.001\right.$ on $16^{\text {th }}$ day), sense problems $\left(0.019\right.$ on $8^{\text {th }}$ day and 0.020 on $16^{\text {th }}$ day), speech problem ( 0.058 on $8^{\text {th }}$ day and 0.041 on $16^{\text {th }}$ day), social contact $(0.005)$. In single item scale teeth $\left(0.019\right.$ on $8^{\text {th }}$ day), opening mouth ( $<0.001$ on $16^{\text {th }}$ day), dry mouth $\left(<0.001\right.$ on $16^{\text {th }}$ day), sticky saliva ( 0.040 on $8^{\text {th }}$ day and $<0.001$ on $16^{\text {th }}$ day), felt ill ( 0.017 on $16^{\text {th }}$ day). Moderately positive correlation was found between post-test knowledge \& practice score.
\end{abstract}

Conclusion: The instructional strategy was effective in increasing knowledge, practice of Head and Neck cancer patients and also improving their Quality of life.

Keywords: Head and neck Cancer patients; Radiation therapy; Instructional strategy; Knowledge practice; QLQ

\section{Introduction}

Cancer is one of the leading causes of adult deaths worldwide. In India International Agency for Research on cancer estimated that average life expectancy of Indian population will increase to 70 Years by 2021 to 2025 . In India more than $75 \%$ cases reported cases of oral cancers are associated with smoke and tobacco consumption. According to the National Cancer Institute, head and neck cancer accounts for nearly 3 percent to 5 percent of all cancer in the United States. These types of cancer are more common in men and in people older than age 50. Around 47, 560 men and women in this country develop head and neck cancer every year [1].

Cancers that are known collectively as head and neck cancers usually begin in the squamous cells that line the moist, mucosal surfaces inside the head and neck. Cancers of the head and neck are further categorized by the area of the head or neck in which they begin. Oral cavity, Pharynx, (nasopharynx, oropharynx) Larynx, Paranasal, sinuses and nasal cavity, Salivary glands [2]. The three main types of treatment for managing head and neck cancer are radiation therapy, surgery and chemotherapy [3]. Surgery where a part or all of the tumor or cancer cells are removed. Chemotherapy where certain drugs are used to kill cancer cells. Radiation therapy where waves of energy are sent to kill cancer cells in and around the tumor. High-energy radiation is delivered to cancer cells or a tumor.

\section{Radiation therapy works in two ways}

- Radiation can stop or slow the growth of the cancer.

- Radiation can shrink tumors, reduce some symptoms, and relieve pain [1]

*Corresponding author: Kaveta Nigam, Department of Nursing, Vivekananda College of Nursing, Lucknow, UP, 226025, India, Tel: 09675343767; E-mail: kavetanigam@gmail.com

Received June 26, 2016; Accepted October 18, 2016; Published October 30, 2016

Citation: Nigam K, Prakash K (2016) Quasi Experimental Non Randomized Study on Effectiveness of Instructional Strategy on Knowledge, Practice and Quality of Life of Head and Neck Cancer Patients Receiving Radiotherapy in Selected Cancer Research Institute, Uttarakhand. J Nucl Med Radiat Ther 7: 313. doi: 10.4172/2155-9619.1000313

Copyright: (ㅇ 2016 Nigam K, et al. This is an open-access article distributed under the terms of the Creative Commons Attribution License, which permits unrestricted use, distribution, and reproduction in any medium, provided the original author and source are credited. 
Citation: Nigam K, Prakash K (2016) Quasi Experimental Non Randomized Study on Effectiveness of Instructional Strategy on Knowledge, Practice and Quality of Life of Head and Neck Cancer Patients Receiving Radiotherapy in Selected Cancer Research Institute, Uttarakhand. J Nucl Med Radiat Ther 7: 313. doi: 10.4172/2155-9619.1000313

Page 2 of 7

Nurses in radiation therapy departments apply evidence-based practice when providing patient and family education and managing side effects [4,5]. Dry mouth (xerostomia) is a common and significant consequence of head and neck radiotherapy. Because of the loss of saliva, patients with xerostomia are more susceptible to periodontal disease, rampant caries, and oral fungal and bacterial infections [6].

Mucositis, characterized by inflammation and ulceration of the oral mucosa, is the most significant acute side effect reported by patients and is a potential source of life-threatening infection. Almost all patients undergoing head and neck radiation therapy experience confluent mucositis by approximately the third week of treatment $[7,8]$ (Figure 1).

Modern equipment and sophisticated treatment planning techniques produce a "skin-sparing" effect, with the therapeutic dose delivered to the target organ, minimizing the dose to the skin. Still, approximately $95 \%$ of patients receiving radiation therapy may experience some degree of skin reaction, ranging from mild erythema to more serious and uncomfortable moist desquamation [9]. Severe moist desquamation results in pain and discomfort, and may require a break in treatment, possibly compromising the effectiveness of treatment [10]. Treatment-related factors, such as type of energy (e.g., photon versus electron), daily dose, size of the treatment field, and use of bolus material (the purpose of which is to increase the dose to the skin surface) affect the degree of skin reaction. Individual patient characteristics also play a role in the development of skin reactions [11] (Figure 2)

QOL is defined by the World Health Organization's Quality of Life Group (WHOQOL, 1993) as follows:

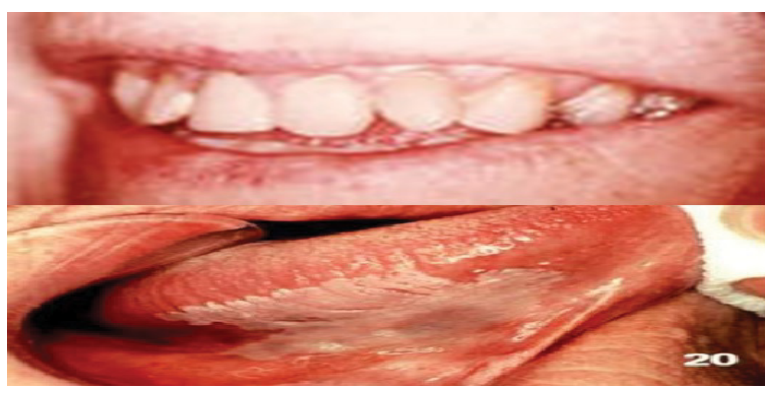

Figure 1: Mucositis.

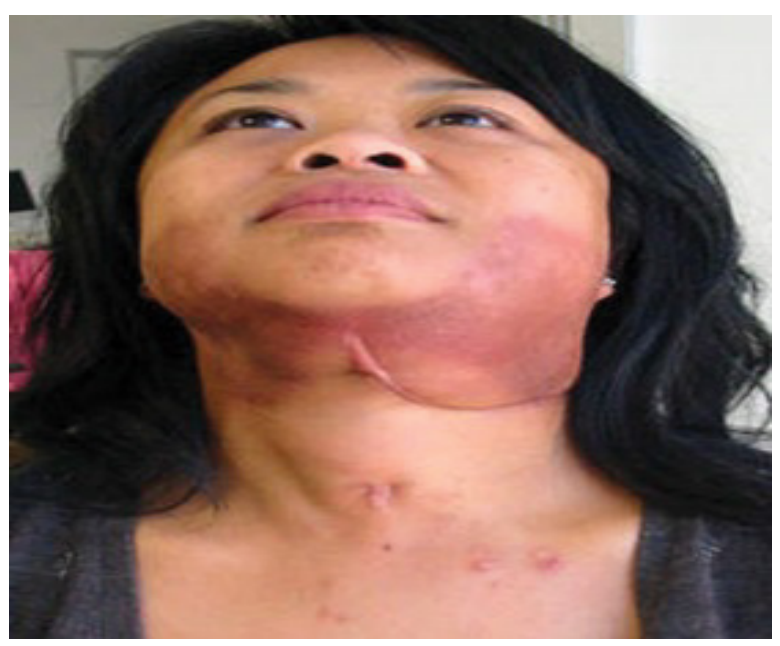

Figure 2: Skin reaction after radiation therapy.
"Quality of life is an individual's perception of their position in life in the context of the culture and value system in which they live and in relation to their goals, expectations, standards and concern. It is a broad ranging concept affected in a complex way by the person's physical health, psychological state, level of independency, social relationship and their relationship to salient features of their environment" [12].

\section{Objective}

- To determine the effectiveness of instructional strategy on the knowledge of head and neck cancer patients receiving radiation therapy.

- To determine the effectiveness of instructional strategy on the practice of head and neck cancer patients receiving radiation therapy.

- To determine the effectiveness of instructional strategy in term of quality of life of cancer patients before and after intervention.

- To find correlation between post-test knowledge score and posttest practice score.

\section{Hypothesis}

All the hypotheses will be tested at $\mathrm{p}<0.05$ significance level.

$\mathrm{H}_{1}$ - The mean post-test knowledge score of head and neck cancer patients in experimental group will be significantly higher than the mean post-test knowledge score of patients in control group.

$\mathrm{H}_{2}$ - The mean post-test practice score of head and neck cancer patients in experimental group will be significantly higher than the mean post- test practice score of patients in control group.

$\mathrm{H}_{3}$ - There will be significant improvement in quality of life of head and neck cancer patients in experimental group than those in control group.

$\mathrm{H}_{4}$ - There will be significant correlation between post-test knowledge score and post-test practice score.

\section{Materials and Methods}

\section{Research design}

Quasi-experimental design with experiment and control group pre-test post- test design.

\section{Setting of the study}

Selected Cancer Research Institute in Dehradun, India.

\section{Sample and sample size}

Head and Neck Cancer Patients undergoing radiation therapy. Sixty Head and Neck Cancer Patients were taken in study thirty in experimental and thirty in control group.

\section{Sampling technique}

Total Enumeration sampling technique.

\section{Inclusion criteria}

The study included the patients of head and neck cancers who were:

- Undergoing radiation therapy at CRI, HIHT.

- Patient who could follow instructions in Hindi/ English language.

- Willing to participate in study.

- Undergone surgery prior to radiation therapy.

- Present during the times of data collection. 


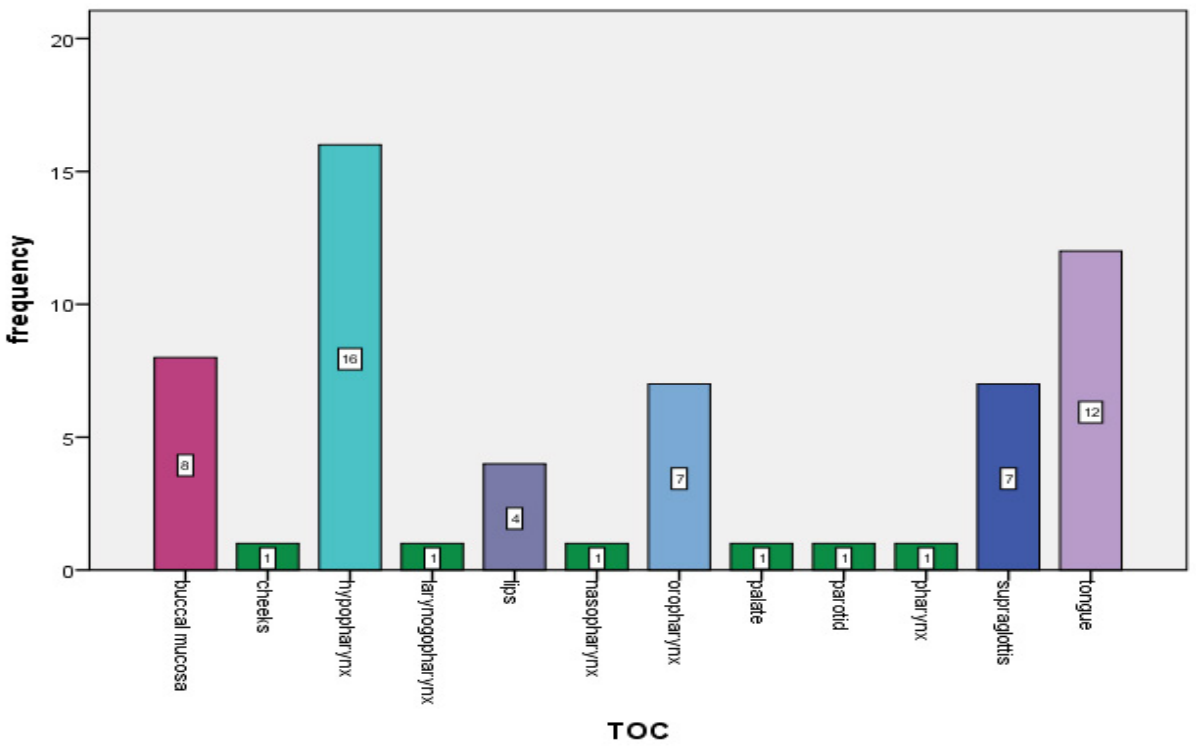

Figure 3: Clinical profile of type of Head and Neck cancer patients undergoing radiation therapy.

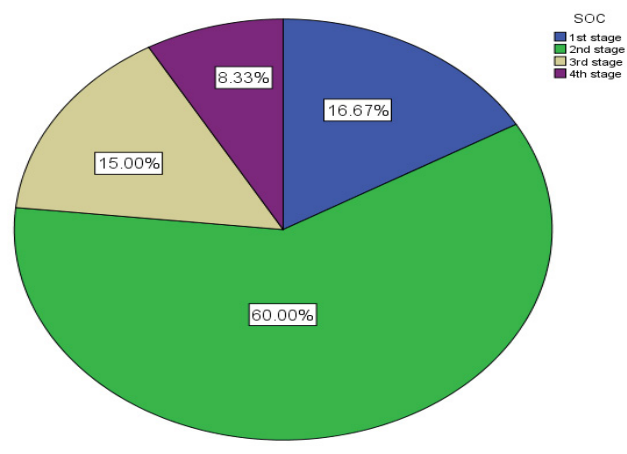

Figure 4: Clinical profiles according to Stage of cancer.

\section{Exclusion criteria}

The study excluded the patients of head and neck cancers who were:

1. Getting Chemotherapy along with radiation.

2. Under the age of 16 year.

The Tool and Instrument Used for the Study

1. Demographic Performa and Clinical Profile of head and neck cancer patients undergoing radiation therapy.

2. H\&N 35 Quality of Life questionnaire

\section{Intervention}

The intervention selected was instructional module carried out for the minimal duration of one hour per day, for a period of one week. Pretest was conducted on the first day of the intervention. Following that, eight and sixteenth day of the intervention the Quality of Life increased progressively in control group and decreased in experimental group were performed in the formative manner. The sessions came to an end with the evaluative phase of taking a Posttest.

\section{Analysis and Results}

The clinical data of Head and Neck cancer patients undergoing radiotherapy, in term of diagnosis out of 60 patients, maximum 16 (26.7\%) were having cancer in hypo pharynx, 12 (20.0\%) were having cancer in tongue, $8(13.3 \%)$ were having cancer in buccal mucosa, 7 (11.7\%) were having cancer in oropharyngeal and supraglottis, 4 (6.7\%) were having cancer in lips, 1 (1.7\%) were having cancer in palate, parotid, pharynx, laryngopharynx, nasopharynx, cheeks.

In stages of cancer in this majority $(61.7 \%)$ were diagnosed in $2^{\text {nd }}$ stage and (8.3\%) were having $4^{\text {th }}$ stage head and neck cancer (Figures 3 and 4 , Tables 1 and 2).

The mean pre-test knowledge of experimental group was $10.50 \pm$ 4.747 which has increased to post-test knowledge score $18.70 \pm 3.064$. Whereas the mean pre-test knowledge of control group was $12.23 \pm$ 4.86 and post-test was $11.50 \pm 5.002$. The calculated ' $t$ ' value was 6.723 which is more than the table value of $2.0(\mathrm{df}=59$ at $\mathrm{p}=0.05$ level $)$ (Table 3$)$.

The mean pre-test practice score of experimental group was 12.50 \pm 3.560 which has increased to $16.40 \pm 1.868$. Whereas the mean pretest practice score of control group was $10.33 \pm 3.198$ and post-test was $10.00 \pm 3.017$. The calculated ' $t$ ' value was 9.878 which is more than the table value of $2.0(\mathrm{df}=59$ at $\mathrm{p}=0.05$ level $)$ (Table 4$)$.

It shows comparison of symptoms and side effect of radiation therapy. Regarding pain among experimental group there was gradual decreased from $1^{\text {st }}$ day to $8^{\text {th }}$ day to $16^{\text {th }}$ day with mean $45.83 \pm 35.27$, $33.61 \pm 22.15,26.66 \pm 9.88$ and within the group p value was 0.050 as compared to control group there was gradual increase $36.38 \pm 25.84$, $56.66 \pm 37.74,71.38 \pm 30.92$ and within the group the $\mathrm{p}$ value was $<0.001$. The difference between both the groups was significant on 8 th $(\mathrm{Z}=2.465, \mathrm{p}=0.014)$ or 16 th day $(\mathrm{Z}=5.178, \mathrm{p} \leq 0.001)$.

Regarding swallowing among experimental group there was reduction in the swallowing difficulty from $1^{\text {st }}$ day to 8 th day and slight increase on $16^{\text {th }}$ day with mean $33.88 \pm 23.46,30.55 \pm 23.70$, $31.11 \pm 45.55$ and within the group $\mathrm{p}$ value was 0.972 as compared to control group there was increase in the swallowing difficulty $28.33 \pm$ $23.22,35.83 \pm 21.34,45.55 \pm 16.91$ within the group $p$ value was 0.012 . The difference between both the groups was significant on 16th day $(\mathrm{Z}=3.656, \mathrm{p} \leq 0.001)$. 
Citation: Nigam K, Prakash K (2016) Quasi Experimental Non Randomized Study on Effectiveness of Instructional Strategy on Knowledge, Practice and Quality of Life of Head and Neck Cancer Patients Receiving Radiotherapy in Selected Cancer Research Institute, Uttarakhand. J Nucl Med Radiat Ther 7: 313. doi: 10.4172/2155-9619.1000313

Page 4 of 7

Regarding sense problem among experimental group there was slight decreased from $1^{\text {st }}$ day to $8^{\text {th }}$ day to $16^{\text {th }}$ day with mean $15.00 \pm$ $27.10,28.88 \pm 18.53,23.33 \pm 17.83$ and within the group $p$ value was 0.015 as compared to control group there was gradual increase $23.33 \pm$ $23.45,17.77 \pm 15.11,14.44 \pm 22.20$ and within the group the $p$ value was 0.192 . The difference between both the groups was significant on 8th $(\mathrm{Z}=2.353, \mathrm{p}=0.019)$ or $16^{\text {th }}$ day $(\mathrm{Z}=2.322, \mathrm{p}=0.020)$.

Regarding speech problem among experimental group there was slight decreased from $1^{\text {st }}$ day to $8^{\text {th }}$ day to $16^{\text {th }}$ day with mean $19.62 \pm$ $24.70,20.37 \pm 16.78,15.92 \pm 8.59$ and within the group p value was 0.515 as compared to control group there was gradual increase 18.14

\begin{tabular}{|c|c|c|c|c|c|}
\hline \multirow{3}{*}{$\begin{array}{l}\text { S. } \\
\text { No. }\end{array}$} & \multirow{3}{*}{ Characteristic } & \multirow{2}{*}{\multicolumn{2}{|c|}{$\begin{array}{c}\text { Control group } \\
\qquad\left(n_{1}=30\right)\end{array}$}} & \multirow{2}{*}{\multicolumn{2}{|c|}{$\begin{array}{c}\text { Experimental group } \\
\qquad\left(n_{1}=30\right)\end{array}$}} \\
\hline & & & & & \\
\hline & & $\mathbf{F}$ & $\%$ & $\mathbf{F}$ & $\%$ \\
\hline \multirow{4}{*}{1.} & \multicolumn{5}{|c|}{ Age } \\
\hline & 20-40 year & 5 & 16.7 & 2 & 6.7 \\
\hline & 41-60year & 16 & 53.3 & 18 & 60 \\
\hline & $\begin{array}{l}61 \text { year and } \\
\text { above }\end{array}$ & 9 & 30.0 & 10 & 3.3 \\
\hline \multirow{3}{*}{2.} & \multicolumn{5}{|c|}{ Gender } \\
\hline & Male & 27 & 90.0 & 23 & 76.7 \\
\hline & Female & 3 & 10.0 & 7 & 23.3 \\
\hline \multirow[t]{6}{*}{3.} & \multicolumn{5}{|c|}{ Educational status } \\
\hline & Illiterate & 7 & 23.3 & 8 & 26.7 \\
\hline & Primary & 17 & 56.7 & 5 & 16.7 \\
\hline & Secondary & 2 & 6.7 & 9 & 30.0 \\
\hline & Graduate & 4 & 13.3 & 5 & 16.7 \\
\hline & Above graduate & 0 & 0.0 & 3 & 10.0 \\
\hline \multirow[t]{3}{*}{4.} & \multicolumn{5}{|c|}{ Place of residence } \\
\hline & Urban & 20 & 66.7 & 16 & 53.3 \\
\hline & Rural & 10 & 33.3 & 14 & 46.7 \\
\hline \multirow[t]{3}{*}{5.} & \multicolumn{5}{|c|}{ Any family history of cancer } \\
\hline & Yes & 0 & 0.0 & 1 & 3.3 \\
\hline & No & 30 & 100 & 29 & 96.7 \\
\hline \multirow[t]{3}{*}{6.} & \multicolumn{5}{|c|}{ Habit of smoking } \\
\hline & Yes & 25 & 83.3 & 19 & 63.3 \\
\hline & No & 5 & 16.7 & 11 & 36.7 \\
\hline \multirow[t]{5}{*}{7.} & \multicolumn{5}{|c|}{ If smoking than year of smoking } \\
\hline & Less than 10 year & 1 & 3.3 & 4 & 13.3 \\
\hline & $10-20$ year & 5 & 16.7 & 4 & 13.3 \\
\hline & 21-30year & 4 & 13.3 & 3 & 10.0 \\
\hline & $\begin{array}{l}\text { More than } 31 \\
\text { year }\end{array}$ & 15 & 50.0 & 8 & 26.7 \\
\hline \multirow[t]{3}{*}{8.} & \multicolumn{5}{|c|}{ Chronic illness in family } \\
\hline & Yes & 1 & 3.3 & 3 & 10 \\
\hline & No & 29 & 96.7 & 27 & 90 \\
\hline \multirow[t]{3}{*}{9.} & \multicolumn{5}{|c|}{ Knowledge of cancer } \\
\hline & Yes & 3 & 10 & 5 & 16.7 \\
\hline & No & 27 & 90 & 25 & 83.3 \\
\hline & & & & & \\
\hline
\end{tabular}

Table 1: Personal profile of the study participants.

\begin{tabular}{|c|c|c|c|c|c|}
\hline $\begin{array}{c}\text { Knowledge } \\
\text { score }\end{array}$ & $\begin{array}{c}\text { Control } \\
\text { group } \\
\text { Mean } \pm \text { SD }\end{array}$ & $\begin{array}{c}\text { Experimental } \\
\text { Mean } \pm \text { SD }\end{array}$ & $\begin{array}{c}\text { Mean } \\
\text { difference }\end{array}$ & t value* & p value \\
\hline Pre test & $12.23 \pm 4.86$ & $10.50 \pm 4.747$ & 1.73 & 1.397 & .168 \\
\hline Post test & $11.50 \pm 5.002$ & $18.70 \pm 3.064$ & 7.2 & 6.723 & $<.001$ \\
\hline *Independent sample 't' test, 't'=2.0 at df=58 and $\mathrm{p}=0.05 ; \mathrm{N}=60$ \\
\end{tabular}

Table 2: To determine the effectiveness of instructional strategy on the knowledge of head and neck cancer patients receiving radiation therapy (Objective 1).

\begin{tabular}{|c|c|c|c|c|c|}
\hline $\begin{array}{c}\text { Practice } \\
\text { score }\end{array}$ & $\begin{array}{c}\text { Control group } \\
\text { Mean } \pm \text { SD }\end{array}$ & $\begin{array}{c}\text { Experimental } \\
\text { Mean } \pm \text { SD }\end{array}$ & $\begin{array}{c}\text { Mean } \\
\text { difference }\end{array}$ & t value* & P value \\
\hline Pre test & $10.33 \pm 3.198$ & $12.50 \pm 3.560$ & 2.167 & 2.480 & 0.016 \\
\hline Post test & $10.00 \pm 3.017$ & $16.40 \pm 1.868$ & 6.40 & 9.878 & $<0.001$ \\
\hline
\end{tabular}

Table 3: To determine the effectiveness of instructional strategy on the practice of head and neck cancer patients receiving radiation therapy (Objective 2).

$\pm 16.11,25.18 \pm 22.20,24.07 \pm 16.26$ and within the group the $p$ value was 0.046 . The difference between both the groups was significant on $8^{\text {th }}$ $(\mathrm{Z}=1.894, \mathrm{p}=0.058)$ or $16^{\text {th }}$ day $(\mathrm{Z}=2.043, \mathrm{p}=0.041)$.

Regarding trouble with social contact among experimental group there was no gradual changes and in control group there was no gradual change in control group. The difference between both the groups was significant on $16^{\text {th }}$ day $(\mathrm{Z}=2.808, \mathrm{p}=0.005)$.

Therefore it could be inferred that instructional strategy was effective in improving the quality of life of patients in experimental group as compared to control group (Table 5).

It shows comparison of symptoms and side effect of radiation therapy. Regarding teeth among experimental group there was gradual increased in $1^{\text {st }}$ day to $8^{\text {th }}$ day and decreased from $8^{\text {st }}$ day to $16^{\text {th }}$ day to $16^{\text {th }}$ day with mean $20.00 \pm 29.81,25.55 \pm 25.79,23.33 \pm 29.23$ and within the group p value was 0.530 as compared to control group there was gradual increase $20.00 \pm 22.48,11.11 \pm 15.98,15.55 \pm 22.71$ and within the group the $\mathrm{p}$ value was 0.230 . The difference between both the groups was significant on 8 th day $(\mathrm{Z}=2.337, \mathrm{p}=0.019)$.

Regarding opening mouth among the experimental group there was slight reduction in opening mouth difficulty from 1st day to 8 th day to 16 th day with mean $41.11 \pm 32.38,38.88 \pm 29.14,33.33 \pm 21.44$ and within the group the $\mathrm{p}$ value was 0.786 as compared to control group there was increased in the opening mouth problem $37.77 \pm$ $31.23,46.66 \pm 29.81,56.66 \pm 26.47$ within the group $\mathrm{p}$ value was 0.038 . The difference between both the groups was significant on 16 th day $(\mathrm{Z}=3.915, \mathrm{p} \leq 0.001)$

Regarding dry mouth among experimental group there was slight increase in the mean from $1^{\text {st }}$ day to $8^{\text {th }}$ day and gradual decreased from $8^{\text {th }}$ to $16^{\text {th }}$ day with mean $46.66 \pm 36.72,51.11 \pm 28.67,41.11 \pm 24.26$ and within the group p value was 0.268 as compared to control group there was increase $36.66 \pm 29.49,57.77 \pm 19.44,93.33 \pm 22.14$ within the group p value was $<0.001$. The difference between both the groups was significant on $16^{\text {th }}$ day $(Z=5.865, p \leq 0.001)$.

Regarding sticky saliva among experimental group there was slight increase in the mean from $1^{\text {st }}$ day to $8^{\text {th }}$ day and gradual decreased from $8^{\text {th }}$ to $16^{\text {th }}$ day with mean $43.33 \pm 39.29,46.6 \pm 34.57,35.55 \pm 24.65$ and within the group p value was 0.357 as compared to control group there was increase $41.11 \pm 32.38,63.33 \pm 25.29,60.00 \pm 25.37$ and within the group $\mathrm{p}$ value was 0.003 . The difference between both the groups was significant on $8^{\text {th }}(Z=2.056, p=0.040)$ and $16^{\text {th }}$ day $(Z=4.030, p \leq 0.001)$.

Regarding felt ill among experimental group there was slight decreased in the mean from $1^{\text {st }}$ day to $8^{\text {th }}$ day and gradual increased from $8^{\text {th }}$ to $16^{\text {th }}$ day with mean $33.33 \pm 35.01,23.33 \pm 24.99,33.33 \pm$ 19.57 and within the group p value was 0.154 as compared to control group there was no gradual changes $30.00 \pm 29.49,23.33 \pm 27.88,22.22$ \pm 22.02 and within the group $p$ value was 0.480 . The difference between both the groups was significant on $16^{\text {th }}$ day $(\mathrm{Z}=2.376, \mathrm{p}=0.017)$. Therefore it could be inferred that instructional strategy was effective in improving the quality of life of patients in experimental group as compared to control group (Figures 4 and 5). 
Citation: Nigam K, Prakash K (2016) Quasi Experimental Non Randomized Study on Effectiveness of Instructional Strategy on Knowledge, Practice and Quality of Life of Head and Neck Cancer Patients Receiving Radiotherapy in Selected Cancer Research Institute, Uttarakhand. J Nucl Med Radiat Ther 7: 313. doi: 10.4172/2155-9619.1000313

Page 5 of 7

\begin{tabular}{|c|c|c|c|c|c|}
\hline EROTC H\&N 35 QLQ & Days & Control Group & Experimental Group & †Z value & $p$ value \\
\hline \multirow{5}{*}{ Pain(HNPA) } & $1^{\text {st }}$ day & $36.38 \pm 25.84$ & $45.83 \pm 35.27$ & 1.165 & .244 \\
\hline & $8^{\text {th }}$ day & $56.66 \pm 37.74$ & $33.61 \pm 22.15$ & 2.465 & 0.014 \\
\hline & $16^{\text {th }}$ day & $71.38 \pm 30.92$ & $26.66 \pm 9.88$ & 5.178 & $<0.001$ \\
\hline & ${ }^{*}$ Within the group & 15.703 & 6.000 & & \\
\hline & $p$ value & $<0.001$ & 0.050 & & \\
\hline \multirow{5}{*}{ Swallowing(HNSW) } & $1^{\text {st }}$ day & $28.33 \pm 23.22$ & $33.88 \pm 23.46$ & 0.972 & 0.331 \\
\hline & $8^{\text {th }}$ day & $35.83 \pm 21.34$ & $30.55 \pm 23.70$ & .839 & 0.402 \\
\hline & $16^{\text {th }}$ day & $45.55 \pm 16.91$ & $31.11 \pm 45.55$ & 3.656 & $<0.001$ \\
\hline & Within the group & 8.889 & 0.057 & & \\
\hline & $\mathrm{p}$ value & 0.012 & 0.972 & & \\
\hline \multirow{5}{*}{ Sense problem(HNSE) } & $1^{\text {st }}$ day & $23.33 \pm 23.45$ & $15.00 \pm 27.10$ & 1.772 & 0.072 \\
\hline & $8^{\text {th }}$ day & $17.77 \pm 15.11$ & $28.88 \pm 18.53$ & 2.353 & 0.019 \\
\hline & $16^{\text {th }}$ day & $14.44 \pm 22.20$ & $23.33 \pm 17.83$ & 2.322 & 0.020 \\
\hline & Within the group & 3.303 & 8.424 & & \\
\hline & $p$ value & 0.192 & 0.015 & & \\
\hline \multirow{5}{*}{ Speech problem(HNSP) } & $1^{\text {st }}$ day & $18.14 \pm 16.11$ & $19.62 \pm 24.70$ & 0.604 & 0.546 \\
\hline & $8^{\text {th }}$ day & $25.18 \pm 22.20$ & $20.37 \pm 16.78$ & 1.894 & 0.058 \\
\hline & $16^{\text {th }}$ day & $24.07 \pm 16.26$ & $15.92 \pm 8.59$ & 2.043 & 0.041 \\
\hline & Within the group & 6.137 & 1.326 & & \\
\hline & $p$ value & 0.046 & 0.515 & & \\
\hline \multirow{5}{*}{ Trouble with social eating(HNSO) } & $1^{\text {st }}$ day & $13.05 \pm 14.29$ & $17.77 \pm 21.52$ & .523 & .601 \\
\hline & $8^{\text {th }}$ day & $16.38 \pm 10.60$ & $23.61 \pm 22.43$ & 1.069 & .285 \\
\hline & $16^{\text {th }}$ day & $16.94 \pm 11.47$ & $16.11 \pm 20.28$ & 1.103 & .270 \\
\hline & Within the group & 3.670 & 4.929 & & \\
\hline & $p$ value & 0.160 & 0.085 & & \\
\hline \multirow{5}{*}{$\begin{array}{l}\text { Trouble with social } \\
\text { contact(HNSC) }\end{array}$} & $1^{\text {st }}$ day & $10.66 \pm 11.15$ & $14.22 \pm 23.98$ & .384 & .701 \\
\hline & $8^{\text {th }}$ day & $9.33 \pm 5.70$ & $16.22 \pm 26.59$ & 1.082 & .279 \\
\hline & $16^{\text {th }}$ day & $4.22 \pm 7.10$ & $13.77 \pm 15.35$ & 2.808 & .005 \\
\hline & Within the group & 7.114 & 0.568 & & \\
\hline & $p$ value & 0.029 & 0.753 & & \\
\hline \multirow{5}{*}{ Less Sexuality(HNSX) } & $1^{\text {st }}$ day & $12.22 \pm 20.02$ & $14.44 \pm 31.17$ & .560 & .575 \\
\hline & $8^{\text {th }}$ day & $22.22 \pm 37.48$ & $16.22 \pm 26.59$ & .043 & .966 \\
\hline & $16^{\text {th }}$ day & $14.44 \pm 32.38$ & $13.33 \pm 22.91$ & 1.188 & .235 \\
\hline & Within the group & 1.937 & 1.968 & & \\
\hline & $p$ value & 0.380 & 0.374 & & \\
\hline
\end{tabular}

Table 4: To determine the effectiveness of instructional strategy in term of quality of life of cancer patients before and after intervention. Comparison of means of results of seven scales in EROTC H\&N 35 quality of life among patients in control and experimental groups (Objective 3 ).

\begin{tabular}{|c|c|c|c|c|c|}
\hline EROTC H\&N 35 QLQ & Days & Control group & Experimental Group & $Z$ value & p value \\
\hline \multirow{5}{*}{ Teeth(HNTE) } & $1^{\text {st }}$ day & $20.00 \pm 22.48$ & $20.00 \pm 29.81$ & 0.580 & 0.562 \\
\hline & $8^{\text {th }}$ day & $11.11 \pm 15.98$ & $25.55 \pm 25.79$ & 2.337 & 0.019 \\
\hline & $16^{\text {th }}$ day & $15.55 \pm 22.71$ & $23.33 \pm 29.23$ & 1.010 & 0.313 \\
\hline & Within the group & 2.943 & 1.268 & & \\
\hline & $p$ value & 0.230 & 0.530 & & \\
\hline \multirow{5}{*}{ Opening mouth (HNOM) } & $1^{\text {st }}$ day & $37.77 \pm 31.23$ & $41.11 \pm 32.38$ & 0.453 & 0.651 \\
\hline & $8^{\text {th }}$ day & $46.66 \pm 29.81$ & $38.88 \pm 29.14$ & 1.179 & 0.238 \\
\hline & $16^{\text {th }}$ day & $56.66 \pm 26.47$ & $33.33 \pm 21.44$ & 3.915 & $<0.001$ \\
\hline & Within the group & 6.564 & 0.481 & & \\
\hline & $p$ value & 0.038 & 0.786 & & \\
\hline \multirow{5}{*}{ Dry mouth(HNDR) } & $1^{\text {st }}$ day & $36.66 \pm 29.49$ & $46.66 \pm 36.72$ & 1.114 & 0.265 \\
\hline & $8^{\text {th }}$ day & $57.77 \pm 19.44$ & $51.11 \pm 28.67$ & 1.354 & 0.176 \\
\hline & $16^{\text {th }}$ day & $93.33 \pm 22.14$ & $41.11 \pm 24.26$ & 5.865 & $<0.001$ \\
\hline & Within the group & 35.657 & 2.630 & & \\
\hline & $p$ value & $<0.001$ & 0.268 & & \\
\hline \multirow{5}{*}{ Sticky saliva(HNSS) } & $1^{\text {st }}$ day & $41.11 \pm 32.38$ & $43.33 \pm 39.29$ & 0.250 & 0.803 \\
\hline & $8^{\text {th }}$ day & $63.33 \pm 25.29$ & $46.6 \pm 34.57$ & 2.056 & 0.040 \\
\hline & $16^{\text {th }}$ day & $60.00 \pm 25.37$ & $35.55 \pm 24.65$ & 4.030 & $<0.001$ \\
\hline & Within the group & 11.732 & 2.062 & & \\
\hline & $p$ value & 0.003 & 0.357 & & \\
\hline
\end{tabular}


Citation: Nigam K, Prakash K (2016) Quasi Experimental Non Randomized Study on Effectiveness of Instructional Strategy on Knowledge, Practice and Quality of Life of Head and Neck Cancer Patients Receiving Radiotherapy in Selected Cancer Research Institute, Uttarakhand. J Nucl Med Radiat Ther 7: 313. doi: 10.4172/2155-9619.1000313

Page 6 of 7

\begin{tabular}{|c|c|c|c|c|c|}
\hline \multirow{5}{*}{ Coughing(HNCO) } & $1^{\text {st }}$ day & $23.33 \pm 21.70$ & $20.00 \pm 29.81$ & 1.219 & 0.223 \\
\hline & $8^{\text {th }}$ day & $13.33 \pm 16.60$ & $24.44 \pm 30.23$ & 1.252 & 0.211 \\
\hline & $16^{\text {th }}$ day & $21.11 \pm 22.28$ & $24.44 \pm 26.16$ & 0.395 & 0.693 \\
\hline & Within the group & 3.037 & 0.677 & & \\
\hline & $p$ value & 0.219 & 0.713 & & \\
\hline \multirow{5}{*}{ Felt ill(HNFI) } & $1^{\text {st }}$ day & $30.00 \pm 29.49$ & $33.33 \pm 35.01$ & 0.159 & 0.874 \\
\hline & $8^{\text {th }}$ day & $23.33 \pm 27.88$ & $23.33 \pm 24.99$ & 0.178 & 0.859 \\
\hline & $16^{\text {th }}$ day & $22.22 \pm 22.02$ & $33.33 \pm 19.57$ & 2.376 & 0.017 \\
\hline & Within the group & 1.470 & 3.747 & & \\
\hline & $p$ value & 0.480 & 0.154 & & \\
\hline \multirow{5}{*}{ Pain killer(HNPK) } & $1^{\text {st }}$ day & $56.67 \pm 50.40$ & $60.00 \pm 49.82$ & 0.260 & 0.795 \\
\hline & $8^{\text {th }}$ day & $66.67 \pm 47.94$ & $76.67 \pm 43.01$ & 0.178 & 0.859 \\
\hline & $16^{\text {th }}$ day & $56.67 \pm 50.40$ & $56.67 \pm 50.40$ & 0.000 & 1.000 \\
\hline & Within the group & 0.783 & 3.444 & & \\
\hline & $p$ value & 0.676 & 0.179 & & \\
\hline \multirow{5}{*}{ Weight loss(HNWL) } & $1^{\text {st }}$ day & $53.33 \pm 50.74$ & $70.00 \pm 46.60$ & 1.317 & 0.188 \\
\hline & $8^{\text {th }}$ day & $90.00 \pm 30.51$ & $90.00 \pm 30.51$ & 0.000 & 1.000 \\
\hline & $16^{\text {th }}$ day & $73.33 \pm 44.97$ & $76.67 \pm 43.01$ & 0.296 & 0.767 \\
\hline & Within the group & 9.10 & 4.00 & & \\
\hline & $p$ value & 0.011 & 0.135 & & \\
\hline
\end{tabular}

Table 5: Comparison of means of results of eleven single item scales in EROTC H\&N 35 quality of life among patients in control and experimental groups.

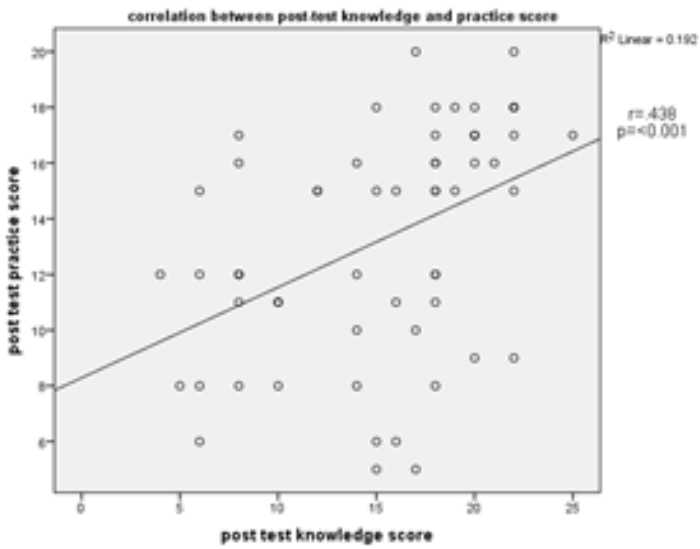

Figure 5: Correlation between post-test knowledge score and post-test practice score.

The above figure shows that there was moderately positive correlation between post-test knowledge and practice score of Karl Pearson $\mathrm{r}=0.438, \mathrm{p} \leq 0.001$ at $5 \%$ level of significance. $\mathrm{P} \leq 0.001$ statistically significant it shows when knowledge increases than the practice also increases.

\section{Discussion}

Patient with Head and Neck Cancer have to deal with the impact of treatment on its physical and psychological aspects. In this study, the Knowledge, Practice and Quality of Life of Head and Neck Cancer patients ranged from poor to good in Experimental Group and Poor to Worsen in Control Group. So for the Quality of life analysis "two Way Friedman tests ' $M$ ' was used which shows there were significantly decreased in Quality of Life in Experimental group. There was maximum decreased in Mean Scores of Quality of life domains in Experimental group. Through the instructional Strategies the knowledge level Mean scored was increased in Experimental group rather than Control Group. The findings of this study reveal that selected instructional strategy for managing side effect of radiation therapy has played an important role in improving the Quality of life of Head and Neck Cancer patients. These results are in tune with an earlier study, which found that teaching practice produced marked improvement in a Quality of life of Head and Neck Cancer patients.

Stephen et al. [12] conducted a study to determine advances in modern radiotherapy (RT), many patients with head and neck cancer (HNC) can be effectively cured, and their health-related quality of life (HR-QoL) has become an important issue. A cross-sectional investigation was conducted to assess the HR-QoL of $640 \mathrm{HNC}$ patients with cancer free survival of more than 2 years. Among them 371 patients were treated by two-dimensional RT (2DRT), 127 by three-dimensional conformal RT (3DCRT), and 142 by intensity-modulated RT (IMRT). A general linear model multivariate analysis of variance was used to analyze the prognosticators of HR-QoL. By multivariate analysis, significant difference $(\mathrm{p}<0.05)$ of HR-QoL outcome by different RT techniques was observed at 2 of the 15 scales in QLQ-C30 and 10 of the 13 scales in $\mathrm{H} \& \mathrm{~N} 35$.

\section{Conclusion}

Based on finding of the study, it is concluded that the instructional module on management of side effects of radiation therapy was significantly effective in improving quality of life of head and neck cancer patients undergoing radiation therapy.

\section{Recommendations}

- A similar study can be conducted on cancer patients undergoing radiation therapy with large sample size.

- A survey can conducted among cancer patients to identify problems experienced by patients while undergoing different treatment modalities for cancer.

- Study can be done to identify the factors affecting the side effect of radiation therapy.

- A prospective community based study can be conducted on the incidence and prevalence of cancer.

- Similar study can be conducted on another type of cancer patient. 
Citation: Nigam K, Prakash K (2016) Quasi Experimental Non Randomized Study on Effectiveness of Instructional Strategy on Knowledge, Practice and Quality of Life of Head and Neck Cancer Patients Receiving Radiotherapy in Selected Cancer Research Institute, Uttarakhand. J Nucl Med Radiat Ther 7: 313. doi: 10.4172/2155-9619.1000313

\section{References}

1. Office for National Statistics (2011) Cancer Incidence and Mortality in the UK 2006-2008. Statistical Bulletin.

2. http://www.cancer.gov/types/head-and-neck/head-neck-fact-sheet

3. http://www.cancer.net/cancer-types/head-and-neck-cancer/treatment-options

4. Parker G (1993) Caring and Disability in Marriage. Buckingham: Open University.

5. Higgs MGJ, Bruner WD, Balmer L, Doneski JJ, Komarny P, et al. (2003) The role of licensed nursing personnel in radiation oncology, Part $A$ : results of a descriptive study, OncolNurs Forum, 30: 51-58.

6. Higgs MGJ, Bruner WD, Balmer L, Doneski JJ, Komarny P, et al. (2003) The role of licensed nursing personnel in radiation oncology. Part B: Integrating the ambulatory care nursing framework. OncolNurs Forum 30: 59-64

7. Brennan MT, Elting LS, Spijkervet FK (2010) Systematic reviews of oral complications from cancer therapies, Oral Care Study Group, MA+SCC/ISOO methodology and quality of the literature. Support Care Cancer 18: 979-984.

8. Foote RL, Loprinizi CL, Frank AR, O'Fallon JR, Gulavita S, et al. (1994) Randomized trial of a chlorhexidine mouthwash for all eviation of radiationinduced mucositis, J ClinOncol 12: 2630-2633.

9. Feight D, Baney T, Bruce S, McQuestion M (2011) Putting evidence into practice: evidence-based interventions for radiation dermatitis. Clin $\mathrm{J}$ Oncol Nurs 15: 481-492.

10. Ryan JL, Bole C, Hickok JT, Moseley FC, Colman L, et al. (2007) Post-treatment skin reactions reported by cancer patients differ by race, not by treatment or expectations, $\mathrm{Br} \mathrm{J}$ Cancer 97: 14-21.

11. W. Yvonne (2000) Nursing interventions in radiation therapy Studies on women with breast cancer Järfälla kopiering och offset, Järfälla, Swedon.

12. Stephen WL, Fwu TL, Yen CC, Ju PC, Ling WT, et al. (2011) Health-related Quality of life in 640 head and neck cancer survivors after radiotherapy using EORTC QLQ-C30 and QLQ-H\&N35 questionnaires. BMC Cancer 11: 128 